\title{
Ecologic salience and agreement on the identification of tree species from Brazilian Atlantic Forest
}

\author{
Natalia Hanazaki ${ }^{1,4}$, Rogério Mazzeo ${ }^{2}$, Alexandre Romariz Duarte 3 , \\ Vinícius Castro Souza ${ }^{2}$ \& Ricardo Ribeiro Rodrigues ${ }^{2}$ \\ ${ }^{1}$ Laboratório de Ecologia Humana e Etnobotânica, Departamento de Ecologia e Zoologia, \\ Universidade Federal de Santa Catarina - UFSC, \\ CEP 88010-970 Florianópolis, SC, Brazil \\ ${ }^{2}$ Departmento de Ciências Biológicas, Universidade de São Paulo - USP, \\ CEP 13418-900 Piracicaba, SP, Brazil \\ ${ }^{3}$ Ministério do Meio Ambiente - MMA, \\ CEP 70068-900 Brasília, DF, Brazil \\ ${ }^{4}$ Corresponding author: Natalia Hanazaki, e-mail: natalia@ccb.ufsc.br
}

HANAZAKI, N., MAZZEO, R., DUARTE, A.R., SOUZA, V.C. \& RODRIGUES, R.R. Ecologic salience and agreement on the identification of tree species from Brazilian Atlantic Forest. Biota Neotrop. 10(1): http:// www.biotaneotropica.org.br/v10n1/en/abstract?article+bn01310012010

\begin{abstract}
This study aims to investigate the consensus among informants in the naming of tree species from a high diversity environment, the Brazilian Atlantic Forest (Sete Barras, SP), through a methodological procedure based on standardized stimuli. Seven selected local experts on tree species used for timber and handicrafts were asked to walk individually across the same area of 1.72 ha and identify and name all the known trees of more than $4 \mathrm{~cm} \mathrm{DBH}$ (diameter at breast height) using common names. All trees were botanically identified, and their DBH and height were measured. The ecologic salience of tree species, expressed in terms of abundance, average height and DBH, was tested in relation to the informants' knowledge and species naming. The guided walks resulted on 708 identification events, with common names corresponding to 122 botanical species, or $68 \%$ of all tree species present. Both the reduced abundance and ecological salience of rare species can explain their recognition. The highest concordances in naming a tree were related only to the species abundance and not to their size (given by diameter and height). In some cases, there is no single common name for a botanical species, reflecting the intrinsic variation in local knowledge, which must be considered in ethnobotanical studies, in ecological assessments based on local knowledge, as well as in community-based conservation and management programs.
\end{abstract}

Keywords: ethnobotany, ethnoecology, local knowledge, parataxonomy.

HANAZAKI, N., MAZZEO, R., DUARTE, A.R., SOUZA, V.C. \& RODRIGUES, R.R. Saliência ecológica e concordância na identificação de espécies arbóreas de Mata Atlântica brasileira. Biota Neotrop. 10(1): http:// www.biotaneotropica.org.br/v10n1/pt/abstract?article+bn01310012010

Resumo: Este estudo visa investigar o consenso entre informantes no reconhecimento e denominação de espécies arbóreas de um ambiente com alta diversidade, a floresta atlântica brasileira (Sete Barras, SP), através de um procedimento metodológico baseado em estímulos padronizados. Foram selecionados sete especialistas locais conhecedores de espécies arbóreas usadas para madeira e artesanatos, que percorreram individualmente uma mesma área de 1,72 ha para identificar e nomear todas as árvores conhecidas com mais de $4 \mathrm{~cm}$ de DAP (diâmetro na altura do peito) através de nomes populares. Todas as árvores foram identificadas botanicamente e tiveram seus DAP e altura determinados. A saliência ecológica das espécies arbóreas, expressa em termos da abundância, da altura média e do DAP, foi testada com relação ao conhecimento de cada informante em nomear as espécies. As caminhadas guiadas resultaram em 708 eventos de identificação, com nomes populares que correspondem a 122 espécies botânicas, ou a $68 \%$ de todas as espécies arbóreas presentes. Tanto a reduzida abundância como a saliência ecológica de espécies raras podem explicar seu reconhecimento. As concordâncias mais elevadas em nomear uma árvore foram relacionadas somente à abundância da espécie e não ao seu tamanho (dado pelo diâmetro e pela altura). Em alguns casos, não há um único nome popular para uma espécie botânica, refletindo a variação intrínseca no conhecimento local, que deve ser considerada em estudos etnobotânicos, nas avaliações ecológicas baseadas no conhecimento local, assim como em programas de manejo e conservação participativos.

Palavras-chave: etnobotânica, etnoecologia, conhecimento local, parataxonomia. 


\section{Introduction}

One of the core questions in studies dealing with traditional and local knowledge is related to how people recognize and name the discontinuities of the biological world (Berlin 1992). Different cultures have different ways to perceive, interpret, name and use the same natural elements, resulting from different ways of interacting with their environment. Nevertheless, universal characteristics underlying traditional and indigenous peoples' classification systems should exist, such as the presence of generic and specific names as binomials (Brown 1985, Berlin 1992, Atran 1998).

Traditional Brazilian people are defined in accordance to several non-exclusive characteristics, such as their intense link with ancestral territories, different languages, equitable forms of social organization, self-denomination, self recognition, and natural resource use, mainly for direct subsistence (Cunha \& Almeida 2000, Diegues \& Arruda 2001). However, there are many local people who are not necessarily characterized as traditional people but who perceive, name, use, and interact with natural elements, creating local systems of biological classification. Examples of such populations are rural people from many countryside areas, whose historical use of the environment is restricted to a recent colonization, when compared to Amerindian groups, for example. This colonization can have occurred since the European arrival in Brazil or even less time, and this is why in some cases the use of the term local instead of "traditional" is recommended. Their "local" knowledge is diverse and dynamic, and shows many regional and local variations. This is one of the reasons for the varying coherence between the correspondences of common (or vernacular) names and botanical species' names.

Berlin et al. (1973) suggested that common names can be assigned into hierarchical folk taxa, with the generic one being the core of an ethnotaxonomic system. In several cases, a folk generic taxon corresponds to a scientific generic or specific taxon, but not in all cases. For some frequent species in different Portuguese-speaking Brazilian regions, the correspondence of many common names for a single botanical species is well known (for example, in the case of juçara, jiçara or palmito, corresponding to Euterpe edulis Mart., or of guapuruvu, bacurubu or garapuvu, corresponding to Schizolobium parahyba (Vell.) S.F.Blake). The same common name can be assigned to different botanical species, depending on the region (for example, the taxon caixeta can correspond to the Bignoniaceae Tabebuia cassinoides (Lam.) DC. in south and southeastern Brazil and to the Simaroubaceae Simarouba amara Aubl. at the Amazon). A single common name can represent a complex of species from the same genus or even of different genera, such as the figueiras (Ficus spp.) or the canelas (Ocotea spp. and Nectandra spp.). We can consider that this perspective is under a substantially emic point of view, e.g. an insider's point of view sensu Harris (1976), but when we turn our sight to some etic (or an outsider's point of view) unfolding of these variations, other questions arise. Following discussions from Oliver \& Beattie (1993), Basset et al. (2004) and Krell (2004), Baraloto et al. (2007) used the term parataxonomy to refer to the "identification of biological specimens by local personnel that have not received formal training in taxonomy and systematic" and etically grouped these limitations of the parataxonomy inventory into "lumping errors", which occur when multiple similar taxa are lumped into a single parataxonomic unit, and "splitting errors", which occur when a single taxonomic species can be split into multiple parataxonomic units, or common names. According to Baraloto et al. (2007), the inaccuracy of parataxonomy may result in economic and ecological shortcomings in regions such as Amazonia, because the harvesting and commercialization in this region are important sources of income for many communities.
For tree species in Atlantic Forest domains, we can find both coherence and variation in the attribution of common names. Beyond the regional variation mentioned, informants from the same region can give different names for the same botanical species. Considering this variation, and depending on the methods used for an ethnobotanical assessment, it is possible to obtain a compilation of few or even only one name for a species that might have one or several common names in one location.

This variation in the local knowledge can be evaluated by examining the consensus of names indicated by informants. Informant consensus is based on a cultural consensus (Romney et al. 1986, Bernard 1995, Phillips 1996) and according to this concept, informants who agree with each other know more about the domain to which these items belong, or are more culturally competent in this domain in particular, than informants who disagree with each other. Informant consensus is widely used to investigate the medicinal properties of plants (Canales et al. 2005, Case et al. 2005) or uses attributed to plants (Galeano 2000), but its notion can also be applied to the concordance or agreement in naming plants. Criticism of this model is that it differentiates cultural from consensual systems (Aunger 1999), but also that it considers the validity of the model in investigating situations where the concordance is not perfect (Romney 1999).

In this sense, it is important to investigate the factors which influence the knowledge of botanical species. For medicinal plants, the availability, life span, and efficacy, among other factors, can affect plant recognition (Stepp \& Moerman 2001, Stepp 2004). For comparisons between species with different uses, the use value can be a determinant factor, since the high agreement about one specific use for a given species can reflect its importance, in comparison with other species (Phillips \& Gentry 1993). In other cases, the use value can have a weak correlation with the species availability, expressed through the importance value index (Torre-Cuadros \& Islebe 2003). According to Albuquerque \& Lucena (2005), the belief that an increase in the abundance of a particular taxa would lead to an increase in its relative importance is based on a simple prediction of the appearance hypothesis, which states that people tend to use the most readily available plants. This proposal was first discussed by Phillips \& Gentry (1993), based on the fact that easily found plants would allow more possibilities for local people to experiment with their uses, and consequently would have a greater probability of being introduced into the local culture. In this sense, more abundant species should be incorporated into the cultural repertoires of useful plants more frequently than rare ones. Albuquerque \& Lucena (2005) provide evidence both supporting and refuting this hypothesis, particularly for medicinal plants. For areas where non-timber forest products are extracted, Lawrence et al. (2005) analyzed local values attributed to harvested plants and show that both the markets and the availability of the taxa influence the value, because as the favorite species become scarce others replace them in perceived importance. However, there is little evidence for the appearance hypothesis when species with only slight differences in their use are considered, such as those areas of Brazilian Atlantic rain forest where there is no conspicuous use of forest resources.

The Brazilian Atlantic Forest is a highly diverse environment (Myers et al. 2000), and many local and traditional people inhabit and interact with the biome, managing and building their ecological knowledge about plants, animals and environmental processes. In contrast with the Amazon forest, the harvest of forest resources occurs on a much smaller scale. The use of trees for timber production nearly ceased half a century ago, and the current use of the forest is mainly related to clandestine palm heart extraction (Silva-Matos \& Bovi 2002). This study aims to investigate the informant coherence in the naming of tree species from an area of mature Atlantic Forest 
in southeastern Brazil through a methodological procedure based on standardized stimuli. Our objectives are to: a) understand how much of the native tree species are known by local residents; b) analyze how much variation exists in the assigned common names at a fine scale; c) analyze if this variation can be related to the ecological salience of tree species, expressed through their abundance, average height and $\mathrm{DBH}$; and d) investigate the individual variation in the assignment of a name for a given species. Based on the variation in the assigned common names, we discuss possible factors influencing such variation. This region is composed of a mosaic of well-preserved rainforest, forest areas in regeneration, and open areas. In a previous study in the same region, Hanazaki et al.(2006) found that the highest diversity of plants known is found in well preserved areas, and this knowledge refers mostly to tree species. Several authors argue that this knowledge is useful for biodiversity conservation (Gadgil et al. 1993, Berkes et al. 2000, Drew 2005). However, the processes underlying the dynamic of this knowledge are poorly known, such as how the knowledge of local people is affected by a high diversity environment.

\section{Methods}

\section{Study site}

This study was carried out between 2001-2002 in the area of Núcleo Sete Barras, Carlos Botelho State Park, Sete Barras municipality, São Paulo State, Brazil. Carlos Botelho State Park is located on Paranapiacaba mountain chain between the coordinates $24^{\circ} 00^{\prime}$ to $24^{\circ} 15^{\prime} \mathrm{S}$ and $47^{\circ} 45^{\prime}$ to $48^{\circ} 10^{\prime} \mathrm{W}$. Its main vegetal formation is the dense rain forest, belonging to the Atlantic Forest domain (Veloso \& Góes-Filho 1982).

Local people are characterized by small families distributed along the banana farms surrounding the park area. They descend mainly from European colonizers with some Amerindian and African influences. Local people are not considered to be traditional people, but are considered to be rural people, with many families occupying the region for less than 60 years. Historical interactions with the forest areas resulted from past timber extraction and game activities and from occasional palm heart collection. There are no residents inside the Carlos Botelho State Park area, and the registers of recent use of the plot area were associated with palm heart extraction, in spite of the fact that the whole park area was exploited for timber before the park was created.

A permanent plot with 10.24 ha is located at Núcleo Sete Barras, where all tree individuals with a diameter at breast height (DBH) greater than $4 \mathrm{~cm}$ were identified and measured (DBH and height) (Rodrigues 2006). Within this plot we defined a route through an area of 1.72 ha, consisting of 172 subplots of $10 \times 10 \mathrm{~m}$. These subplots were contiguous and were defined according to the following criteria: a variety of areas were included within the plot in order to include a higher tree diversity, and existing tracks were used inside the plot to avoid the impact of stepping on seedlings.

The plot has a mountain relief, with declivity between 2 and $90 \%$, and altitudes between 455 to $560 \mathrm{~m}$; the climate is mesotermic and sub-tropical without a dry season, and with hydric excedents predominating between 218 and $518 \mathrm{~mm}$, mainly in October and March. Average temperatures in the coldest month are between -3 and $18{ }^{\circ} \mathrm{C}$ (Rodrigues 2006).

\section{Data collection and analysis}

Based on 58 interviews conducted in a previous study and on field observations (Hanazaki et al. 2006), we used purposive sampling (Tongco 2007) to select seven male informants according to the fol- lowing criteria: a) informants were indicated to be the local experts on tree species used for timber and handicrafts; $b$ ) informants live close to the protected area; and c) informants were available to participate of the data collection. The selected informants were asked to walk across the 172 subplots, identifying and naming all the known trees with more than $4 \mathrm{~cm} \mathrm{DBH}$ according to their common names. Informants visited the plots separately and followed the same tracks within the plots in order to keep a standardized stimulus. Each individual tree recognized and named by a common name by the informant corresponded to one identification event in our study. The work with each informant lasted for three to four hours. Data about the uses of tree species were described by Hanazaki et al. (2006).

To test the correlation between tree identification and its ecological parameters, we correlated the number of identification events with species abundance, with its average height, and with its average DBH. For correlations between the number of identification events, the number of identified species, and informant age, as well as correlations between the number of identification events and ecological parameters of the species (abundance, DBH and height) we used Spearman correlations (Zar 1996). Medium values were compared through $\mathrm{t}$ tests. The normality of the data was previously tested through the D'Agostino test (Ayres et al. 2003).

In order to analyze the correspondence between folk generic taxa and botanical species, we performed an analysis based on informant consensus regarding the common names of each tree species (or the common names considered as synonyms according to the informants) using the following Equation 1:

$$
\mathrm{A}=\mathrm{Nb} / \mathrm{Nq}
$$

where A is the agreement in the informants' naming of each folk generic taxa, $\mathrm{Nb}$ is the number of times each common name was given to the same botanical species, and $\mathrm{Nq}$ is the number of times that the common name was given to any botanical species. Thus, a value of $\mathrm{A}=1.00$ corresponds to $100 \%$ agreement in the informants' naming of a botanical species.

For example, folk generic taxa mandegaú was given in 36 identification events $(\mathrm{Nq}=36)$, and in 26 times it was related to the species Tetrastylidium grandifolium (Baill.) Sleumer $(\mathrm{Nb}=26)$. The agreement in the informant's naming is $A=26 / 36$, or 0.72 .

However, the number of identification events of each botanical species varied because the species have different abundances and the informants have different affinities for different species. Based on Friedman et al. (1986) and Amorozo \& Gély (1988) we used a correction factor based on the relative popularity (RP) of each folk generic taxa mentioned, given by RP, the number of times a folk generic taxa was named divided by the number of citations of the folk generic taxon most cited. RP equals 1.00 for the folk generic taxon with the highest number of identification events, while other values are defined proportionally. The corrected agreement (Ac) is given by the relationship Equation 2:

$$
\mathrm{Ac}=\mathrm{A} \times \mathrm{RP}
$$

In our former example, the relative popularity of mandegaú is given by $\mathrm{RP}=36 / 43=0.84$ and the corrected agreement is given by $\mathrm{Ac}=0.72 \times 0.84=0.60$.

Spearman correlation coefficients were also used to verify correlations between the corrected agreement index and the abundance, $\mathrm{DBH}$, and height of each tree species.

\section{Results}

In the 1.72 ha area, there were 180 tree species and 1,869 individuals with a $\mathrm{DBH}$ greater than $4 \mathrm{~cm}$. The average height was 8.22 
$\mathrm{m}$ ( standard deviation $=4.46 \mathrm{~m}$ ) and the average DBH was $15.57 \mathrm{~cm}$ (s.d. =15.06). This analysis excludes two species due to their obvious distinctive characteristics for both the interviewers from the Hanazaki et al. (2006) study and the informants from the present study: Euterpe edulis Mart. (juçara or palmito) and Alsophila sternbergii (Sternb.) Conant (xaxim). The 180 tree species used in this study have different distributions, and the most abundant among the recognized species were: Guapira opposita (Vell.) Reitz, Tetrastylidium grandifolium (Baill.) Sleumer, Garcinia gardneriana (Planch. \& Triana) Zappi and Rudgea jasminoides (Cham.) Müll. Arg., which each had more than 60 individuals. On the other hand, other species were represented by only one individual in the whole 1.72 ha area, such as Coccoloba glaziovii Lindau, Cytharexylum myrianthum Cham., Dalbergia frutescens (Vell.) Britton, Dendropanax cuneatum Decne. \& Planch., Jacaratia spinosa (Aubl) ADC., Maytenus communis Reiss. and Phytolacca dioica $\mathrm{L}$. These seven rare species have approximately twice the average height of all species (average height $=16.43 \mathrm{~m}$, s.d. $=5.13 \mathrm{~m}$ ) and have more than three times the average DBH of all species (average $\mathrm{DBH}=57.05 \mathrm{~cm}$ ). In this sense, rare species can be very apparent due to their size.

All the informants were born in the region and used to work close to the forest. Two of them currently have as their main labor activity the work in banana plantations, two were retired, one used to produce charcoal, and two informants occasionally help researchers during their fieldwork in ecological studies in the region. Most of them have some background in palm heart extraction or timber extraction in the past. The walks with the informants resulted in 708 identification events, with common names corresponding to 122 botanical species ( $68 \%$ of all tree species present in the 1.72 ha area). The average informant age was 55.57 years (s.d. $=25.24)$, and varied from 24 to 79 years. Each informant named 103.14 individuals on average (s.d. $=60.14$ ), and identified 54.71 different botanical species $($ s.d. $=26.38)$ through 48.43 common names $($ s.d. $=19.59)$ on average. There was no statistical correlation between informant age and the number of identification events ( $r s=0.43, \mathrm{p}>0.34)$ or between informant age and the number of species recognized and named ( $r s=0.61, p>0.15$ ). Less than $2 \%$ of all identified species were identified by all informants, and almost half of the species (45\%) were identified by only one, or at most two, informants (Figure 1), already showing the great variation in the individual knowledge.

All correlations between tree identification and its ecological parameters were positive and statistically significant. There was a significant correlation between the number of identification events and

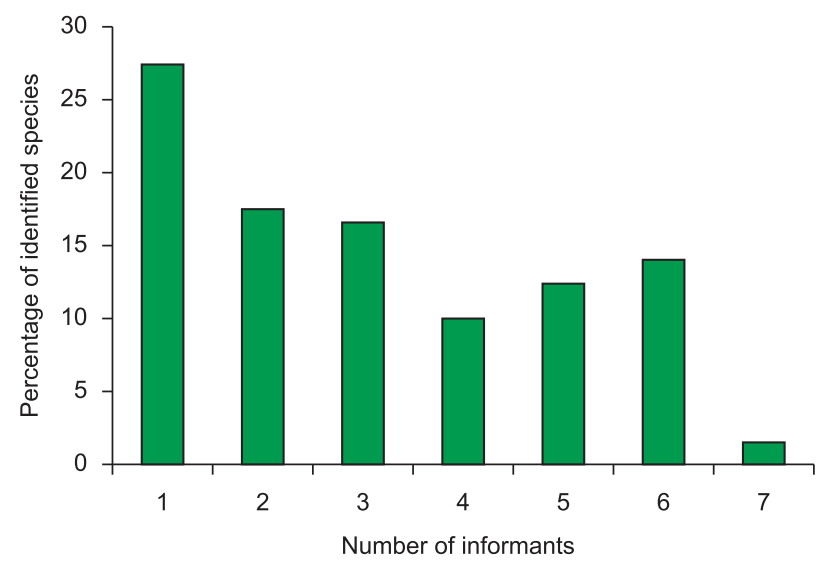

Figure 1. The percentage of identified species according to the number of informants who identified each of the 120 tree species ( $n=7$ informants) in the study area within the Atlantic Forest in Carlos Botelho State Park, Brazil. species abundance $(\mathrm{rs}=0.42, \mathrm{t}=5.06, \mathrm{p}<0.01 ; \mathrm{n}=120)$, between the number of identification events and average height ( $\mathrm{rs}=0.23$, $\mathrm{t}=2.52, \mathrm{p}<0.01 ; \mathrm{n}=118$ ), and between the number of identification events and the average DBH $(\mathrm{rs}=0.28, \mathrm{t}=3.11, \mathrm{p}<0.01 ; \mathrm{n}=119)$ (Figure 2). Despite their significance, the low values for correlations
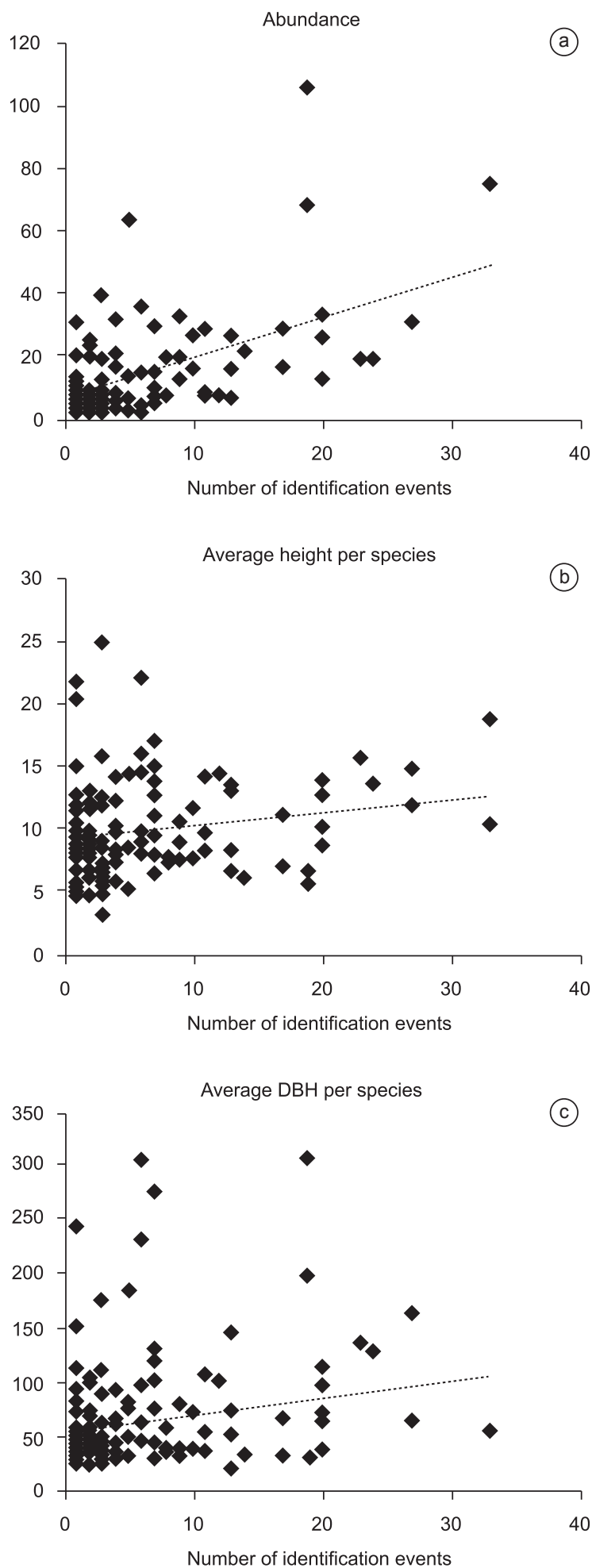

Figure 2. Correlations between the number of identification events for each species $(\mathrm{n}=120)$ in the study area in Atlantic Forest, Carlos Botelho State Park, Brazil and: a) species abundance; b) average height per species; and c) average DBH (diameter at breast height) per species. 
between the number of identification events and average height and DBH indicate that variables other than ecological salience should be taken into account. In other words, not all large and big trees are perceived in the same way, yet abundant species are the most recognized ones.

The 182 common names given by the informants correspond to 156 folk generic taxa, according to the hierarchical taxonomic arrangement proposed by Berlin et al. (1973). Among the 182 common names, there are at least 26 names considered to be synonyms by the informants. We considered different names as synonyms when more than one informant clearly stated that these different names were

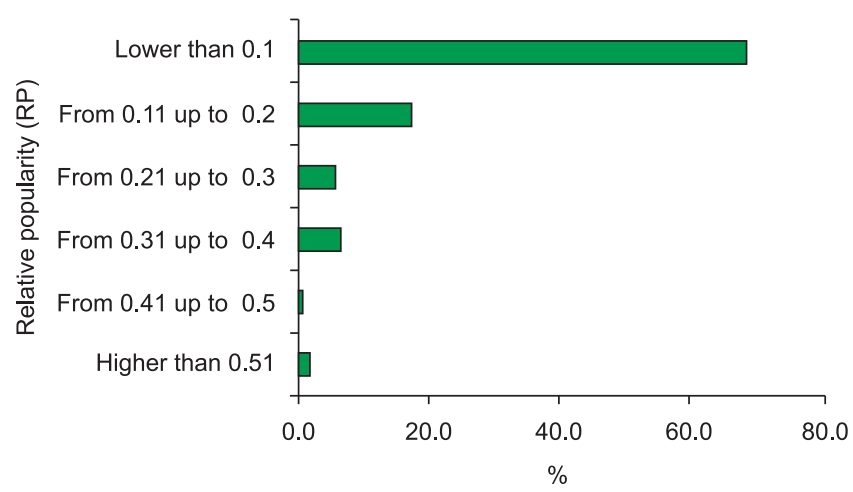

Figure 3. The percentage of folk generic taxa $(n=156)$ according to their relative popularity, in the study area within Atlantic Forest, Carlos Botelho State Park, Brazil. attributed to the same taxon. Three generic taxa had four common synonyms, one taxon had three common synonyms and 15 taxa had two synonyms. For example, common names ceboleiro, pau-d'alho, cebolão and imbu were considered synonyms (one taxon, Phytolacca dioica L. and four synonyms); and canela-branca and niutinga were considered to be synonyms (one taxon, Cryptocarya moschata Nees \& Mart. and two synonyms).

The correspondence between generic folk taxa and botanical species varied. To assess the relative popularity, we considered the number of citations of the folk generic taxon most frequently recognized (43 times for a tree known as both nhambiúva, nhandeúva, farinha-seca, or galinha-choca). For the species with a relative popularity higher than $\mathrm{RP}=0.20$ (32 taxa, or approximately $15 \%$ of the species) (Figure 3), and with at least two identification events corresponding to the same common name (31 taxa), the agreement on the common names given varied between less than 5 and $100 \%$ (Table 1). Most species had low values of relative popularity (up to 0.20 ), or were cited very few times when compared with the number of citations of the folk generic taxon most cited.

The most recognized trees were used for their wood (e.g., construction of houses and some furniture; manufacturing of handles; manufacturing of canoes, fence posts, and wooden wagons), or for other purposes such as firewood or food (edible fruits eaten raw or used to attract small mammals and birds) (Hanazaki et al. 2006). Only two species from Table 1 were also recognized for their medicinal use (Virola bicuhyba Warb. and Hymenaea courbaril L.), which can reflect their relevance for recognition. Hanazaki et al. (2006) showed that most of the medicinal species known and used in this region were

Table 1. Agreement in the local identification of species with relative popularity higher than 0.20 and at least $50 \%$ of consensus, for a studied area of Atlantic Forest at Carlos Botelho State Park, Brazil $(\mathrm{Nb}=$ number of times each common name was given to the same botanical species, $\mathrm{Nq}=$ number of times that the common name was given to any botanical species, $\mathrm{A}=$ agreement in the informants' naming of each folk generic taxa, $\mathrm{RP}=$ relative popularity, Ac $=$ corrected agreement; see text for further details).

\begin{tabular}{|c|c|c|c|c|c|c|c|}
\hline Popular names and synonyms & Species & Family & $\mathbf{N b}$ & $\mathbf{N q}$ & $\mathbf{A}$ & $\mathbf{R P}$ & Ac \\
\hline $\begin{array}{l}\text { Nhambiúva, nhandeúva, farinha-seca, } \\
\text { galinha-choca }\end{array}$ & Sloanea spp. ${ }^{1}$ & Elaeocarpaceae & 33.00 & 43.00 & 0.77 & 1.00 & 0.77 \\
\hline Mandegaú & Tetrastylidium grandifolium (Baill.) Sleumer & Olacaceae & 26.00 & 36.00 & 0.72 & 0.84 & 0.60 \\
\hline Urucurana & Hyeronima alchorneoides Allem & Phyllanthaceae & 17.00 & 19.00 & 0.89 & 0.44 & 0.40 \\
\hline Bucuva & Virola bicuhyba Warb. & Myristicaceae & 17.00 & 17.00 & 1.00 & 0.40 & 0.40 \\
\hline Vacupari & Garcinia gardneriana (Planch. \& Triana) Zappi & Clusiaceae & 16.00 & 17.00 & 0.94 & 0.40 & 0.37 \\
\hline Canela-branca, niutinga & Cryptocarya moschata Nees \& Mart. & Lauraceae & 14.00 & 16.00 & 0.88 & 0.37 & 0.33 \\
\hline Guajipiroca, goiabinha-de-casca-escura & Marlierea spp. ${ }^{2}$ & Myrtaceae & 13.00 & 16.00 & 0.81 & 0.37 & 0.30 \\
\hline Embaúva, embaúva-vermelha & Cecropia glaziovii Snethl. & Urticaceae & 11.00 & 11.00 & 1.00 & 0.26 & 0.26 \\
\hline Araçá & Marlierea spp. ${ }^{2}$ & Myrtaceae & 11.00 & 15.00 & 0.73 & 0.35 & 0.26 \\
\hline Tapiá & Alchornea glandulosa Poepp. \& Endl. & Euphorbiaceae & 9.00 & 14.00 & 0.64 & 0.33 & 0.21 \\
\hline Fumão, fumo-bravo, folha-larga & Bathysa australis K.Schum. & Rubiaceae & 9.00 & 9.00 & 1.00 & 0.21 & 0.21 \\
\hline Pau-de-sangue, sangueiro & Pterocarpus rohrii Vahl & Fabaceae & 8.00 & 9.00 & 0.89 & 0.21 & 0.19 \\
\hline Jatobá & Hymenaea courbaril L. & Fabaceae & 7.00 & 10.00 & 0.70 & 0.23 & 0.16 \\
\hline Murta & Eugenia spp. ${ }^{3}$ & Myrtaceae & 6.00 & 9.00 & 0.67 & 0.21 & 0.14 \\
\hline Cauvi & Pseudopiptadenia warmingii Benth. & Fabaceae & 6.00 & 11.00 & 0.55 & 0.26 & 0.14 \\
\hline Pau-pimenta & Capsicodendron dinisii (Schwacke) Occhioni & Canellaceae & 6.00 & 12.00 & 0.50 & 0.28 & 0.14 \\
\hline Pau-marfim, marfim & Chrysophyllum viride Mart. \& Eichl. ex Miq. & Sapotaceae & 5.00 & 7.00 & 0.71 & 0.16 & 0.12 \\
\hline Tabocuva, tabucuva & Capsicodendron dinisii (Schwacke) Occhioni & Canellaceae & 5.00 & 7.00 & 0.71 & 0.16 & 0.12 \\
\hline Areticu & Rollinia sericea R.E.Fr. & Annonaceae & 5.00 & 9.00 & 0.56 & 0.21 & 0.12 \\
\hline Ipê & Tabebuia serratifolia Nichols. & Bignoniaceae & 4.00 & 7.00 & 0.57 & 0.16 & 0.09 \\
\hline Jequitibá & Cariniana estrellensis Kuntze & Lecythidaceae & 4.00 & 7.00 & 0.57 & 0.16 & 0.09 \\
\hline Ceboleiro, pau-d’alho, cebolão, imbu & Phytolacca dioica $\mathrm{L}$. & Phytolaccaceae & 4.00 & 8.00 & 0.50 & 0.19 & 0.09 \\
\hline
\end{tabular}

Corresponding to Sloanea monosperma Vell., Sloanea guianensis (Aubl.) Benth., Sloanea obtusifolia (Moric.) K. Schum

Correspondig to Marliera suaveolens Cambess., Marlierea obscura O. Berg

Corresponding to Eugenia platysema O. Berg., Eugenia cuprea (O. Berg.) Nied., Eugenia schuechiana O. Berg., Eugenia subavenia O. Berg 
herbaceous, cultivated or collected near the houses and not inside the mature forest areas, except for some tree species such as Virola bicuhyba Warb. and Hymenaea courbaril L.

The 23 folk taxa shown in Table 1 include 12 botanical species and three genus and correspond to those taxa with at least $50 \%$ of agreement in the local identifications. Excluding the 34 species which
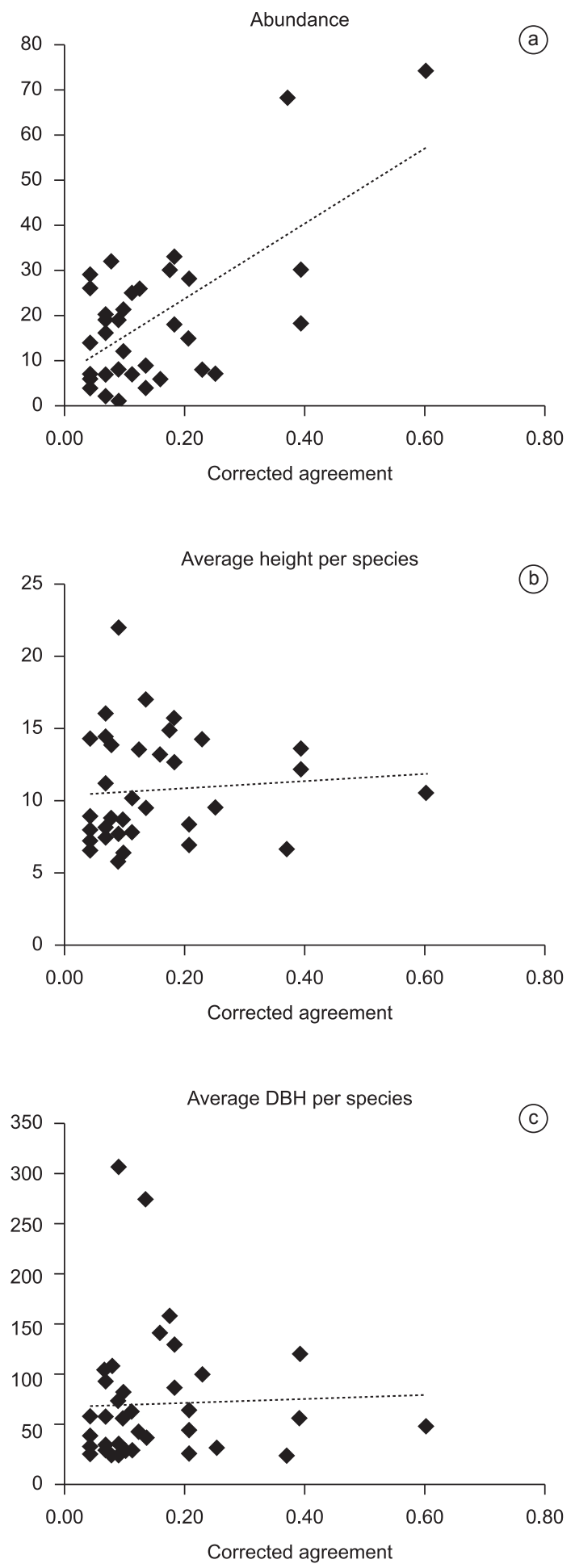

Figure 4. Correlations between the corrected agreement values per species $(n=20)$ in the study area within Atlantic Forest, Carlos Botelho State Park, Brazil and: a) species abundance; b) average height per species; and c) average DBH (diameter at breast height) per species. had only one identification event, these 12 species and three genus make up $24 \%$ of the remaining species. Three taxa can include more than one species: the genus Sloanea includes S. monosperma Vell., S. guianensis (Aubl.) Benth. and S. obtusifolia (Moric.) K. Schum.; the genus Eugenia includes E. platysema O. Berg., E. cuprea (O. Berg.) Nied., E. schuechiana O. Berg., and E. subavenia O. Berg., and the genus Marlierea includes species M. suaveolens Cambess. and M. obscura O. Berg. This latter genus was named as both guajipiroca and araçá, reflecting some confusion between both scientific species and folk generic taxa during the attribution of common names. This confusion can be due to the similar green trunk of $M$. suaveolens and M. obscura.

Values of corrected agreement for species in Table 1 were correlated with ecological parameters, except for the three generic taxa (Sloanea, Marlierea e Eugenia), and used an average Ac (corrected agreement) for the two names given to Capsicodendron dinisii (Schwacke) Occhioni. For species with the highest corrected agreement values (Table 1), there was a significant correlation at the $5 \%$ significance level only between corrected agreement and species abundance ( $\mathrm{rs}=0.52, \mathrm{t}=2.43, \mathrm{p}<0.05, \mathrm{n}=18$ ), but not between corrected agreement and average height $(\mathrm{rs}=-0.10, \mathrm{t}=-0.41$, $\mathrm{p}>0.05, \mathrm{n}=18)$ or average DBH $(\mathrm{rs}=-0.20, \mathrm{t}=-0.84, \mathrm{p}>0.05$, $\mathrm{n}=18$ ) (Figure 4).

The variation in the common names given for each species also occurred when the informants were analyzed separately, in what we will refer to as "internal agreement". For a single informant, the largest number of times the same species was identified in identification events was eight, such as in the case of $T$. grandifolium, named eight times by informant \#3. In seven identification events, this informant named T. grandifolium as mandegaú and in one identification event he named it as canela, showing $87.5 \%$ of internal agreement. There were other cases with $100 \%$ internal agreement, such as in the case of informant \#4 in seven identification events for T. grandifolium, identified as mandegaú, for informant \#5 in five identification events of G. gardneriana, identified as vacuparí, and for informant \#3 in six identification events for $M$. suaveolens, identified as araçá. However, there were also cases with a lower internal agreement observed, such as in the case of informant \#5, who identified Cariniana estrellensis (Raddi) Kuntze as peroba five times and also provided two other common names for this species, resulting in an internal agreement value of $60 \%$. Similarly, informant \#3 gave five different names for G. opposita in five identification events, with no internal agreement at all (the five different common names given were: canela, pau-dá'gua, tapaçaré, tapiá and vatinga). Identification mistakes may have occurred among the informants, however we assumed that the emic perspective was more important rather than an etic judgment about the informant answer.

\section{Discussion}

This study deals with a highly diverse environment, but the tree species investigated have a low number of uses. The dependency on the tree resources from this forest area should have declined in the last decades, based on the inferences about the intensive past use of timber and the prohibition of this use nowadays. The high biodiversity in terms of natural availability of tree species was also reflected in a high diversity of species recognized and identified: almost $68 \%$ of these species were recognized and named by seven informants. In Costa Rica, Chazdon \& Coe (1999) found that $70 \%$ of 459 woody species had some utility. For the Afro-American people from Colombian Choco, Galeano (2000) found that almost $63 \%$ of the 331 available tree species had a use. Among the Bolivian Tacana, $62 \%$ of the 185 species had a utility (DeWalt et al. 1999). Among 
the Gouronsi in Burkina Faso, Kristensen \& Balslev (2003) found that $74 \%$ of the 110 woody species were identified by local people. In the Northeastern Brazilian Atlantic forest, Cunha \& Albuquerque (2006) found that the local people recognized more than $95 \%$ of the tree species, yet the richness was considerably lower and the area studied was considerably smaller ( 42 species in a 0.2 ha area) than in the present study. Although number of informants and methods used in those studies varied, we can observe that two thirds or more of the woody plants were recognized in different environments, regardless of the number of available species.

The number of identification events was correlated with the abundance, height, and DBH of the plants. In the current study, the ecological salience of the species can explain its recognition, supporting the hypothesis that the visibility of a plant influences its recognition, through its abundance or size. In spite of the fact that the ecological abundance of each tree species seemed to influence its identification, there are some remarkable exceptions when rare species are considered. Rare or infrequent species can be recognized due to their size, expressed by their high diameter or height. Since we are dealing with a cultural domain restricted to a few uses, the salience of a tree can be given by its abundance, reflecting a higher probability of encounter, and, if the species is rare, to its diameter and height. This association between size and salience was already suggested by other authors, such as Hunn (1999) for the perceptual salience in recognizing the biodiversity, which combines the ecological salience and the size factor of a given species. However, when considering not only the recognition but also the consensus in the naming of a tree, the highest concordances were related only to a species' abundance and not to its size (given by diameter and height). This means that rare or infrequent species can be recognized by their size, but there is not a high agreement in their names.

We observed no correlation between the age of the informants and the number of identification events, or between informant age and the number of identified species. For plants with medicinal uses, several authors have found that the knowledge tended to be accumulated with age, thus older people tend to know more medicinal species than younger people (Phillips \& Gentry 1993, Hanazaki et al. 2000). The same trend has not observed for other uses, such as edible species and handicraft and wood species (Phillips \& Gentry 1993, Kristensen \& Balslev 2003, Lykke et al. 2004), in spite of the expectation that some accumulation of knowledge occurs with the accumulation of experience. More informants are required to test trends regarding age and informant's knowledge more thoroughly.

A high richness of recognized and named species does not mean a high coherence in such identifications. Less than half of the species were identified by one or two informants and only $2 \%$ of the species were identified by all seven informants, reflecting the fact that most of the knowledge about tree species available is not shared among all informants, even though these seven informants were indicated as the experts about tree knowledge in this region. The local knowledge about tree species is not homogeneous, indicating a high variation in the local knowledge about a diversified assemblage of tree species. In this sense, a common, popular, or vernacular name of a tree species should be viewed with caution: in some cases, there is not a single correct common name for a botanical species. Even the same local expert can assign different names for the same botanical species.

The cases of internal disagreement could have influenced the previous results for to two main reasons. The first reason is related to the possible human errors while the informant identifies a species. The second is based on the fact that we are dealing with comparisons between scientific names and common names, expecting that both systems were established similarly (Berlin 1992). However, a group of species can be clustered under one name in the folk taxonomy, given their morphological characteristics. From an academic point of view, this is what Baraloto et al. (2007) referred to as lumping errors. From a local point of view, the lack of agreement among local experts does not imply that they are not culturally competent in the studied domain (rainforest trees), but can reflect an intrinsic variation in the local knowledge.

This variation emphasizes the importance of a careful investigation of local and botanical names matching in ethnobotanical studies, especially when local knowledge is considered for conservation purposes (Drew 2005). This point also applies to ecological assessments based on local knowledge and to community based management programs. As pointed out by many authors, the consequences of putting together many species under one common name or, conversely, assigning several common names for the same botanical species, are the obvious over- or under-estimations of species counts in biodiversity inventories (Basset et al. 2004, Krell 2004, Oliver \& Beattie 1993, Baraloto et al. 2007). Thus, a challenge in ethnobotanical and traditional ecological knowledge studies is how to consider such variation, or such diversity in the local knowledge, when there is not a single correct name for each botanical species. This variation occurs not only among informants with different social roles, gender or age, but also among those with similar expertise.

\section{Acknowledgements}

The authors acknowledge all the local residents who agreed to take part in this research, especially the seven key local collaborators. This research was supported by FAPESP within the Biodiversity Virtual Institute Program (www.biota.org.br). N. Hanazaki thanks to FAPESP post-doctoral grant (01/05596-1), to J. L. C. Maia, director of Carlos Botelho State Park, to the anonymous reviewers, and to an insightful commentary of J.G. Marques about the misinterpretation of the term ethnospecies.

\section{References}

ALBUQUERQUE, U.P.A. \& LUCENA, R.F.P. 2005. Can apparency affect the use of plants by local people in tropical forests? Interciencia 30(8):506-511.

AMOROZO, M.C.M. \& GÉLY, A. 1988. Uso de plantas medicinais por caboclos do Baixo Amazonas, Barcarena, Pará. Bol. Mus. Para. Emílio Goeldi 4(1):47-130.

ATRAN, S. 1998. Folk biology and the anthropology of science: cognitive universals and cultural particulars. Behav. Brain. Sci. 21(4):547-609.

AUNGER, R. 1999. Against idealism/contra consensus. Curr. Anthropol. 40(suppl.):93-101.

AYRES, M., AYRES JUNIOR, M., AYRES, D.L. \& SANTOS A.A.S. 2003. BioEstat 3.0: aplicações estatísticas nas áreas de ciências biológicas e médicas. Sociedade Civil Mamirauá, Belém.

BARALOTO, C., FERREIRA, E., ROCKWELL, C. \& WALTHIER, F. 2007. Limitations and applications of parataxonomy for community forest management in southwestern Amazonia. Ethnobot. Res. Appl. 5:77-84.

BASSET, Y., NOVOTNY, V., MILLER, S.E., WEIBLEN, G.D., MISSA, O. \& STEWART, A.J.A. 2004. Conservation and biological monitoring of tropical forests: the role of parataxonomists. J. Appl. Ecol. 41(2):163-174.

BERKES, F., COLDING, J. \& FOLKE, C. 2000. Rediscovery of traditional ecological knowledge as adaptive management. Ecol. Appl. 10(5):1251-1262.

BERLIN, B. 1992. Ethnobiological classification. Princeton University Press, Princeton.

BERLIN, B., BREEDLOVE, D.E. \& RAVEN, P.E. 1973. General principles of classification and nomenclature in Folk Biology. Am. Anthropol. 75(1):214-242. 
BERNARD, H.R. 1995. Research methods in anthropology: qualitative and quantitative approaches. 2 ed. Altamira, Walnut Creek.

BROWN, C. 1985. Mode of Subsistence and Folk Biological Taxonomy. Curr. Anthropol. 26(1):43-64.

CANALES, M., HERNÁNDEZ, T., CABALLERO, J., VIVAR, A.R., AVILA, G., DURAN, A. \& LIRA, R. 2005. Informant consensus factor and antibacterial activity of the medicinal plants used by the people of San Rafael Coxcatlán, Puebla, México. J Ethnopharmacol. 97(3):429-439.

CASE, R.J., PAULI, G.F. \& SOEJARTO, D.D. 2005. Factors in maintaining indigenous knowledge among ethnic communities of Manus Island. Econ. Bot. 59(4):356-365.

CHAZDON, R.L. \& COE, F.G. 1999. Ethnobotany of woody species in second-growth, old-growth, and selectively logged forests of northeastern Costa Rica. Cons. Biol. 13(6):1312-1322.

CUNHA, M.C. \& ALMEIDA, M.W.B. 2000. Indigenous people, traditional people and conservation in the Amazon. Daedalus 129(2):315-338.

CUNHA, L.V. \& ALBUQUERQUE, U.P. 2006. Quantitative ethnobotany in an atlantic forest fragment of northeastern Brazil: implications to conservation. Environ. Monit. Assess. 114(1-3):1-25.

DEWALT, S.J., BOURDY, G., CHÁVEZ-MICHEL, L.R. \& QUENEVO, C. 1999. Ethnobotany of the Tacana: quantitative inventories of two permanent plots of northwestern Bolivia. Econ. Bot. 53(3):237-260.

DIEGUES, A.C.S. \& ARRUDA, R.S.V. 2001. Saberes tradicionais e biodiversidade no Brasil. Ministério do Meio Ambiente, Brasília.

DREW, J.A. 2005. Use of traditional ecological knowledge in marine conservation. Cons. Biol. 19(4):1286-1293.

FRIEDMAN, J., YANIV, Z., DAFNI, A. \& PALEWITCH, D. 1986. A preliminary classification of the healing potential of medicinal plants, based on a rational analysis of an ethnopharmacological field survey among Bedouins in the Negev Desert, Israel. J. Ethnopharmacol. 16(23):275-287.

GADGIL, M., BERKES, F. \& FOLKE, C. 1993. Indigenous knowledge for biodiversity conservation. Ambio 22(2-3):151-156.

GALEANO, G. 2000. Forest use at the pacific coast of Choco, Colombia: a quantitative approach. Econ. Bot. 54(3):358-376.

HANAZAKI, N., SOUZA, V.C. \& RODRIGUES, R.R. 2006. Ethnobotany of rural people from the boundaries of Carlos Botelho State Park, São Paulo, Brazil. Acta Bot. Bras. 20(4):889-909.

HANAZAKI, N., TAMASHIRO, J.Y., LEITÃO FILHO, H.F. \& BEGOSSI, A. 2000. Diversity of plants uses in two Caicara communities from the Atlantic Forest coast, Brazil. Biod. Cons. 9(5):597-615.

HARRIS, M. 1976. History and significance of the Emic/Etic distinction. Ann. Rev. Anthropol. 5:329-340.

HUNN, E. 1999. Size as limiting the recognition of biodiversity in folkbiological classifications: one of four factors governing the cultural recognition of biological factors. In Folkbiology (D.L. Medin \& S. Atran, eds.). MIT Press, Boston, p. 47-70.

KRELL, F.T. 2004. Parataxonomy vs. taxonomy in biodiversity studies: pitfalls and applicability of "morphospecies" sorting. Biod. Cons. 13(4):795-812.
KRISTENSEN, M. \& BALSLEV, H. 2003. Perceptions, use and availability of woody plants among the Gourounsi in Burkina Faso. Biod. Cons. 12(8):1715-1739.

LAWRENCE, A., PHILLIPS, O., REATEGUI, A., LOPEZ, M., ROSE, S., WOOD, D. \& JOSÉ, A. 2005. Local values for harvested forest plants in Madre de Dios, Peru: towards a more contextualised interpretation of quantitative ethnobotanical data. Biod. Cons. 14(1):45-79.

LYKKE, A.M., KRISTENSEN, M.K. \& GANABA, S. 2004. Valuation of local use and dynamics of 56 woody species in the Sahel. Biod. Cons. 13(10):1961-1990.

MYERS, N.R.A., MITTERMEIER, C., MITTERMEIER, G., FONSECA, G.A B. \& KENT, J. 2000. Biodiversity hot spots for conservation priorities. Nature 403(6772):853-858.

OLIVER, I. \& BEATTIE, A.J. 1993. A possible method for the rapid assessment of biodiversity. Cons. Biol. 7(3):562-568.

PHILLIPS, O.L. 1996. Some quantitative methods for analyzing ethnobotanical knowledge. In Selected guidelines for ethnobotanical research: a field manual (M.N. Alexiades, ed.). The New York Botanical Garden, New York, p. 171-198.

PHILLIPS, O. \& GENTRY, A.H. 1993. The Useful Plants of Tambopata, Peru: II. Additional Hypothesis Testing in Quantitative Ethnobotany. Econ. Bot. 47(1):33-43.

RODRIGUES, R.R. 2006. Diversidade dinâmica e conservação em florestas do Estado de São Paulo: 40ha de parcelas permanentes. In Anais do 57 Congresso Nacional de Botânica. Sociedade Botânica do Brasil, Porto Alegre, p. 354-558.

ROMNEY, A.K. 1999. Culture consensus as a statistical model. Curr. Anthropol. 40(S1):103-115.

ROMNEY, A.K., WELLER, S.C. \& BATCHELDER, W.H. 1986. Culture as consensus: a theory of culture and informant accuracy. Am. Anthropol. 88(2):313-338.

SILVA-MATOS, D.M. \& BOVI, M.L.A. 2002. Understanding the threats to biological diversity in southeastern Brazil. Biod. Cons. 11(10):1747-1758.

STEPP, J.R. 2004. The role of weeds as sources of pharmaceuticals. J. Ethnopharmacol. 92(2-3):163-166.

STEPP, J.R. \& MOERMAN, D.E. 2001. The importance of weeds in ethnopharmacology. J. Ethnopharmacol. 75(1):19-23.

TONGCO, M.D.C. 2007. Purposive sampling as a tool for informant selection. Ethnobot. Res. Appl. 5:147-158.

TORRE-CUADROS, M.D.L.A. \& ISLEBE, G.A. 2003. Traditional ecological knowledge and use of vegetation in southeastern Mexico: a case study from Solferino, Quintana Roo. Biod. Cons. 12(12):2455-2476.

VELOSO, H.P. \& GÓES FILHO, L. 1982. Fitogeografia brasileira: classificação fisionômico-ecológica da vegetação Neotropical. Ministério das Minas e Energia, Salvador.

ZAR, J.H. 1996. Biostatistical analysis. 3 ed. Prentice-Hall, London.

Received 10/09/09 Revised 18/01/10 Accepted 4/02/10 